\title{
Targeting the Serotonin 5-HT 7 Receptor in the Search for Treatments for CNS Disorders: Rationale and Progress to Date
}

\author{
Agnieszka Nikiforuk
}

Published online: 27 February 2015

(C) The Author(s) 2015. This article is published with open access at Springerlink.com

\begin{abstract}
The 5- $\mathrm{HT}_{7}$ (5-hydroxytryptamine 7, serotonin 7) receptor is one of the most recently identified members of the serotonin receptor family. Pharmacological tools, including selective antagonists and, more recently, agonists, along with $5-\mathrm{HT}_{7}$ receptor $\left(5-\mathrm{HT}_{7} \mathrm{R}\right)$ knock-out mice have revealed the involvement of this receptor in central nervous system processes. Its well-established role in controlling body temperature and regulating sleep and circadian rhythms has implicated this receptor in mood disorders. Thus, the $5-\mathrm{HT}_{7} \mathrm{R}$ has gained much attention as a possible target for the treatment of depression. Although preclinical data support the antidepressant-like actions of $5-\mathrm{HT}_{7} \mathrm{R}$ antagonists, their clinical efficacy has not been yet established. Other evidence has implicated the $5-\mathrm{HT}_{7} \mathrm{R}$ in learning and memory. Preclinical findings suggest that blockade of this receptor may be beneficial against schizophrenia-like cognitive deficits. Other possible indications include nociception, epilepsy, migraine, autism spectrum disorders, and Rett Syndrome. However, the question is whether the beneficial effects may be achieved by activation or blockade of $5-\mathrm{HT}_{7} \mathrm{Rs}$. Hence, this review briefly summarises the recent findings on the role of 5- $\mathrm{HT}_{7} \mathrm{Rs}$ and their ligands in CNS disorders.
\end{abstract}

\section{Key Points}

5-hydroxytryptamine $7\left(5-\mathrm{HT}_{7}\right)$ receptors not only play a physiological role in the regulation of the central nervous system (CNS) but also may be involved in pathological processes.

Thus, these receptors represent a potential therapeutic target for treating CNS disorders.

However, whether therapeutic efficacy can be achieved via activation or blockade of the $5-\mathrm{HT}_{7}$ receptor remains uncertain.

\section{Introduction}

The 5-hydroxytryptamine 7 receptor $\left(5-\mathrm{HT}_{7} \mathrm{R}\right)$ was cloned in 1993 by independent laboratories [1-3]. To date, several splice variants have been described $[4,5]$, but the only functional difference that has been reported so far is a differential pattern of receptor internalisation displayed by the human $5-\mathrm{HT}_{7} \mathrm{R}$ (d) isoform [6]. This receptor, belonging to the G-protein-coupled receptor (GPCR) superfamily, is positively coupled to adenylate cyclase through the stimulatory $\mathrm{G} \alpha$ s proteins, and its activation results in an increase in cyclic adenosine monophosphate (cAMP). In addition, it has been recently demonstrated that the $5-\mathrm{HT}_{7} \mathrm{R}$ interacts not only with the $\mathrm{G} \alpha$ s but also with $\mathrm{G} \alpha 12$ proteins [7]. The dynamic palmitoylation can represent a molecular mechanism responsible for selective Gas- or G $\alpha 12$-mediated signalling [8]. Recent evidence suggests that $5-\mathrm{HT}_{7} \mathrm{R} /$ $\mathrm{G} \alpha 12$ signalling in the hippocampus undergoes strong developmental regulation with a pronounced transient 
increase during early postnatal stages and may represent a molecular mechanism by which serotonin specifically modulates the formation of initial neuronal networks [9]. The pharmacology and signal transductions of $5-\mathrm{HT}_{7} \mathrm{Rs}$ may be even more complicated, as it has been recently demonstrated that these receptors may form homodimers [10]; the heterodimerisation with $5-\mathrm{HT}_{1 \mathrm{~A}} \mathrm{R}$ has also been reported [11].

\section{Ligands of 5-HT 7 Receptors}

Several $5-\mathrm{HT}_{7} \mathrm{R}$ antagonists are available, including the nonselective antagonist DR-4004 [12] and several selective antagonists such as SB-258719 [13], SB-269970 [14], SB656104 [15] and JNJ-18038683 [16] (Table 1). In the absence of selective agonists of $5-\mathrm{HT}_{7} \mathrm{Rs}$, unselective compounds such as 5-carboxamidotryptamine or 8-hydroxy-2(dipropylamino)tetralin (8-OH-DPAT) $\left(5-\mathrm{HT}_{1 \mathrm{~A}} /{ }_{7} \mathrm{R}\right.$ agonist) have often been used. More recently, various selective $5-\mathrm{HT}_{7} \mathrm{R}$ agonists have been identified (reviewed in detail by Di Pilato et al. [17]), including AS-19 [18], LP-44 [19], LP-12 [19], LP-211 [20], and E-55888 [18] (Table 1). The purpose of this review is to summarize existing data on the effects of $5-\mathrm{HT}_{7} \mathrm{R}$ ligands in animal models of central nervous system (CNS) disorders. When available, clinical data are also discussed.

\section{Depression}

A converging body of evidence has shown that the selective blockade of $5-\mathrm{HT}_{7} \mathrm{Rs}$ displays an antidepressant-like activity in commonly used preclinical tasks, i.e. in the tail suspension test (TST) in mice as well as in the forced swim test (FST) in both mice and rats [16, 21-26]. Specifically, $5-\mathrm{HT}_{7} \mathrm{R}$ knock-out (KO) mice showed an antidepressantlike behavioural profile as revealed by reduced immobility in the FST and TST [21-23]. In line with genetic inactivation effects, the pharmacological blockade of $5-\mathrm{HT}_{7} \mathrm{Rs}$ by the selective antagonist SB-269970 also exerted antidepressant-like activities in the TST [22, 24, 25] as well as in the FST in both mice [22, 25] and rats [26]. JNJ18038683 was also effective in the mouse TST [16]. Moreover, the efficacy of SB-269970 was also assessed in the olfactory bulbectomy paradigm, which is considered a behavioural model of agitated depression [27]. Interestingly, SB-269970 produced a faster antidepressant-like response than the commonly prescribed selective serotonin reuptake inhibitor (SSRI) antidepressant fluoxetine.

In addition to exerting a distinct antidepressant-like action, the blockade of $5-\mathrm{HT}_{7} \mathrm{Rs}$ may also augment the behavioural effects of antidepressant drugs. For example,
SB-269970, administered at a dose not exerting a significant antidepressant effect, enhanced the action of subeffective doses of antidepressant drugs, including the SSRI citalopram, in the TST and FST in mice [23, 24, 28].

$5-\mathrm{HT}_{7} \mathrm{R}$ may also represent a clinically relevant target for the treatment of depression. It has been suggested that the clinically established antidepressant effect of certain antipsychotics, such as amisulpride, aripiprazole or lurasidone, is most likely mediated by the $5-\mathrm{HT}_{7} \mathrm{R}[23,29,30]$. In fact, functional $5-\mathrm{HT}_{7} \mathrm{Rs}$ were required to reveal the antidepressant-like effects of those drugs in the TST and FST in mice [23, 29, 30]. Moreover, one clinical study evaluated the efficacy of JNJ-18038683, a selective antagonist of $5-\mathrm{HT}_{7} \mathrm{Rs}$, as an antidepressant in patients with major depressive disorder [16]. There was no statistically significant improvement over a placebo on the Montgomery-Åsberg Depression Rating Scale (MADRS) after either JNJ-18038683 or escitalopram administration. Thus, due to a lack of assay sensitivity, the interpretation of these results is inconclusive.

\section{Stress}

Prolonged stress is a major risk factor for depression, and stress-based animal models represent a useful instrument for mimicking depressive-like symptomatology [31]. It has been proposed that the modulatory role for serotonin in the stress-evoked hypothalamic-pituitary-adrenal axis response may involve $5-\mathrm{HT}_{7} \mathrm{Rs}$ [32]. Recent data suggest that chronic restraint stress-induced endocrine disruption may be associated with the increased function and expression of 5- $\mathrm{HT}_{7} \mathrm{Rs}$ [33]. Consequently, pharmacological blockade of adrenocortical 5- $\mathrm{HT}_{7} \mathrm{Rs}$ could be of therapeutic benefit for overcoming endocrine disruption in stress-related diseases. Moreover, 5- $\mathrm{HT}_{7} \mathrm{Rs}$ may also be involved in the response of neural circuits to repeated stress. Repeated corticosterone administration, a model known to mimic some aspects of stress exposure, increased the reactivity of rat CA3 hippocampal circuitry to the activation of $5-\mathrm{HT}_{7} \mathrm{Rs}$ [34]. Moreover, the selective $5-\mathrm{HT}_{7} \mathrm{R}$ antagonist SB269970 counteracted restraint stress-induced attenuation of long-term potentiation in the rat frontal cortex [35]. It has also been demonstrated that exposure to chronic mild stress evokes up-regulation of 5- $\mathrm{HT}_{7} \mathrm{R}$ messenger RNA (mRNA) in the rat hippocampus and hypothalamus, and these changes were counteracted by the antidepressant fluoxetine [36]. In addition, data from our laboratory indicate that the administration of SB-269970 reversed the stress-induced cognitive deficit in rats [37]. In line with data demonstrating that selective blockade of $5-\mathrm{HT}_{7} \mathrm{Rs}$ augmented the behavioural effects of antidepressants, SB-269970, administered at an inactive dose, enhanced the pro-cognitive 
Table 1 The behavioural effects of 5-HT 7 Rs ligands

\begin{tabular}{|c|c|c|c|}
\hline $\begin{array}{l}\text { Compound/ } \\
\text { indication }\end{array}$ & Effect & Dose $^{\mathrm{a}}$ & References \\
\hline \multicolumn{4}{|c|}{ 5-HT ${ }_{7} \mathrm{R}$ antagonists } \\
\hline \multicolumn{3}{|c|}{ SB-258719: 3-methyl- $N$-[(1 R)-1-methyl-3-(4-methyl-1-piperidinyl)propyl]- $N$-methylbenzenesulfonamide } & [13] \\
\hline Epilepsy & Antiepileptic activity in the WAG/Rij rat model of absence epilepsy & 10 & [93] \\
\hline \multicolumn{3}{|c|}{ SB-258741: R-(+)-1-(toluene-3-sulfonyl)-2-[2-(4-methylpiperidin-1-yl)ethyl]-pyrrolidine } & [110] \\
\hline \multirow[t]{2}{*}{ Schizophrenia } & Reversal of amphetamine-induced hyperactivity & $2.3-9.1$ & [75] \\
\hline & Normalisation of PCP-disrupted PPI & $2.3-9.1$ & [75] \\
\hline \multicolumn{3}{|c|}{ SB-269970: (2 R)-1-[(3-hydroxyphenyl)sulfonyl]-2-[2-(4-methyl-1-piperidinyl)ethyl]pyrrolidine } & {$[14,110]$} \\
\hline \multirow[t]{5}{*}{ Depression } & Antidepressant-like effect in the FST and TST in mice & 10 & [22] \\
\hline & Antidepressant-like effect in the TST in mice & $3-30$ & [24] \\
\hline & Antidepressant-like effect in the FST and TST in mice & $5-10$ & [25] \\
\hline & Antidepressant-like effect in the FST in rats & $1.25-2.5$ & [26] \\
\hline & Antidepressant-like effect in olfactory bulbectomised rats & 2 & [27] \\
\hline \multirow[t]{2}{*}{ Sleep } & REM sleep-suppressive effect in rats & 10 & {$[24]$} \\
\hline & REM sleep-suppressive effect in rats & $10-20$ & [39] \\
\hline $\begin{array}{r}\text { Circadian } \\
\text { rhythms }\end{array}$ & Blockade of 8-OH-DPAT-induced a phase advance in the rat SCN slices & $0.01 \mu \mathrm{M}$ & {$[44]$} \\
\hline Anxiety & $\begin{array}{l}\text { Anxiolytic-like effects in the Vogel drinking test and the elevated plus-maze test in rats as well } \\
\text { as in the four-plate test in mice }\end{array}$ & $0.5-1$ & {$[25]$} \\
\hline OCD & Reduced marble burying in mice & 10 & [53] \\
\hline \multirow[t]{5}{*}{ Cognition } & Improvement of reference memory in a radial arm maze task in rats & 1 & [67] \\
\hline & Deficit in novel location test in mice & 10 & {$[56]$} \\
\hline & Improvement of cognitive flexibility in the ASST in rats & 1 & [37] \\
\hline & Improvement of object recognition memory in the NORT in rats & 30 & [58] \\
\hline & Deficits in object recognition memory in the NORT in mice & $3-10$ & [59] \\
\hline \multirow[t]{11}{*}{ Schizophrenia } & Reversal of amphetamine- and ketamine-induced hyperactivity in mice & $10-30$ & [74] \\
\hline & Reversal of PCP-induced hyperactivity in rats & 30 & {$[58]$} \\
\hline & Reversal of the amphetamine-induced PPI deficits in mice & 30 & {$[74]$} \\
\hline & $\begin{array}{l}\text { Reversal of MK-801-induced deficits in an autoshaping Pavlovian instrumental learning task in } \\
\text { rats }\end{array}$ & $3-10$ & {$[81]$} \\
\hline & $\begin{array}{l}\text { Reversal of intra-prefrontal ketamine-induced deficits in rats' autoshaping Pavlovian } \\
\text { instrumental learning task }\end{array}$ & $1 \mu \mathrm{g}$ & {$[82]$} \\
\hline & Reversal of the PCP-induced deficits in reversal learning & $3-10$ & [79] \\
\hline & $\begin{array}{l}\text { Reversal of the MK-801-induced impairment in working memory on a rat delayed non- } \\
\text { matching to position task }\end{array}$ & 10 & {$[80]$} \\
\hline & Reversal of PCP-induced deficits in the NORT in rats & 1 & [83] \\
\hline & Reversal of ketamine-induced deficits in the NORT in rats & 1 & [77] \\
\hline & Reversal of ketamine-induced cognitive inflexibility on the ASST in rats & 1 & [77] \\
\hline & Reversal of ketamine-induced social withdrawal in rats & 1 & [77] \\
\hline Epilepsy & Antiepileptic activity in a pilocarpine-induced rat model of temporal lobe epilepsy & 10 & [94] \\
\hline \multirow[t]{2}{*}{ Migraine } & Inhibition the 5-CT-induced dilatation in the middle meningeal artery in rats & 1 & {$[100]$} \\
\hline & Reduction of neurogenic dural vasodilation in rats & $5-10$ & [101] \\
\hline \multicolumn{3}{|c|}{ SB-656104: 6-[(R)-2-[2-[4-(4-chlorophenoxy)-piperidin-1-yl]-ethyl]-pyrrolidine-1-sulfonyl]-1 H-indole } & [15] \\
\hline Sleep & REM sleep-suppressive effect in rats & 30 & [15] \\
\hline Schizophrenia & $\begin{array}{l}\text { Reversal of MK-801-induced learning and memory impairments in the passive avoidance and } \\
\text { Morris water maze tests in rats }\end{array}$ & $10-30$ & [84] \\
\hline \multicolumn{3}{|c|}{$\begin{array}{l}\text { JNJ-18038683: 3-(4-chlorophenyl)-1,4,5,6,7,8-hexahydro-1-(phenylmethyl)pyrazolo[3,4-d]azepine 2-hydroxy-1,2,3- } \\
\text { propanetricarboxylate }\end{array}$} & [16] \\
\hline
\end{tabular}


Table 1 continued

\begin{tabular}{|c|c|c|c|}
\hline $\begin{array}{l}\text { Compound/ } \\
\text { indication }\end{array}$ & Effect & $\operatorname{Dose}^{\mathrm{a}}$ & References \\
\hline Depression & Antidepressant-like effect in the TST in mice & $0.3-1$ & [16] \\
\hline \multirow[t]{2}{*}{ Sleep } & REM sleep-suppressive effect in rats & $1-10$ & [16] \\
\hline & REM sleep-suppressive effect in healthy human volunteers & $20 \mathrm{mg}$ & [16] \\
\hline $\begin{array}{r}\text { Circadian } \\
\text { rhythms }\end{array}$ & Blockade of 8-OH-DPAT-induced and photic phase shifts of wheel running activity in mice & 10 & [45] \\
\hline \multicolumn{4}{|l|}{ 5-HT ${ }_{7} \mathrm{R}$ agonists } \\
\hline \multicolumn{2}{|c|}{ AS-19: [(2 S)-(+)-5-(1,3,5-trimethylpyrazol-4-yl)-2-(dimethylamino)tetralin] } & & [18] \\
\hline Cognition & $\begin{array}{l}\text { Improvement of long-term memory but impairment of short-term memory in an autoshaping } \\
\text { Pavlovian/instrumental learning task in rats }\end{array}$ & $1-10$ & {$[62,63]$} \\
\hline $\begin{array}{r}\text { Circadian } \\
\text { rhythms }\end{array}$ & $\begin{array}{l}\text { Shortened the period length of PER2 bioluminescence in explants of SCN from PER2::LUC } \\
\text { mice }\end{array}$ & $0.01-0.1 \mu \mathrm{M}$ & [47] \\
\hline \multirow[t]{4}{*}{ Pain } & Reversal of capsaicin-induced mechanical hypersensitivity in mice & $3-10$ & [18] \\
\hline & Hyperalgesic effects in a mice model of nerve injury & $0.1-10$ & [88] \\
\hline & Hyperalgesic effects in a rat model of nerve injury & $2.5-10$ & [89] \\
\hline & Reversal of thermal hyperalgesia in streptozotocin-induced experimental diabetes in mice & 10 & {$[90]$} \\
\hline Epilepsy & Pro-epileptic activity in a pilocarpine-induced rat model of temporal lobe epilepsy & 10 & [94] \\
\hline Migraine & Increase in neurogenic dural vasodilation in rats & $5-10$ & [101] \\
\hline \multicolumn{2}{|c|}{ LP-211: $N$-(4-cyanophenylmethyl)-4-(2-diphenyl)-1-piperazinehexanamide] } & & {$[20]$} \\
\hline Sleep & REM sleep-suppressive effect in rats & $5-10$ & [41] \\
\hline $\begin{array}{r}\text { Circadian } \\
\text { rhythms }\end{array}$ & Induction of phase advance in mice & 0.25 & [46] \\
\hline Anxiety & Anxiolytic-like effects in the black and white box test and the dark/light test in mice & 0.25 & [46] \\
\hline Cognition & Improvement of long-term memory in an autoshaping Pavlovian/instrumental learning task & 1 & {$[64]$} \\
\hline Rett syndrome & $\begin{array}{l}\text { Reversal of anxiety-related behaviour in a light/dark test, motor performance in a Dowel test } \\
\text { and memory deficits in the novelty preference task in a mice model of the Rett syndrome }\end{array}$ & 0.25 & [99] \\
\hline \multicolumn{2}{|c|}{ E-55888: dimethyl-[2-[3-(1,3,5-trimethyl-1 H-pyrazol-4-yl)-phenyl]-ethyl]amine] } & & [18] \\
\hline \multirow[t]{3}{*}{ Pain } & Reversal of capsaicin-induced mechanical hypersensitivity in mice & $3-10$ & {$[18]$} \\
\hline & Increase of the analgesic potency of morphine & 10 & [111] \\
\hline & Hyperalgesic effects in a rat model of nerve injury & 10 & [89] \\
\hline
\end{tabular}

Only studies demonstrating efficacies (or impairing effects) are included

ASST attentional set-shifting task, FST forced swim test, NORT novel object recognition test, $O C D$ obsessive-compulsive disorder, $P C P$ phencyclidine, PPI prepulse inhibition, REM rapid eye movement, SCN suprachiasmatic nuclei, TST tail suspension test, 5-CT 5-carboxamidotryptamine

${ }^{\mathrm{a}}$ Doses are $\mathrm{mg} / \mathrm{kg}$ unless otherwise indicated

efficacy of an inactive dose of the SSRI escitalopram [37]. Thus, the stress-evoked enhancement of $5-\mathrm{HT}_{7} \mathrm{R}$-mediated responses or up-regulation of their expression may purportedly account for the efficacy of the $5-\mathrm{HT}_{7} \mathrm{R}$ antagonist in ameliorating stress-induced abnormalities. Nevertheless, it should be noted that the relation between stress, glucocorticoids and $5-\mathrm{HT}_{7} \mathrm{R}$ expression and function seems to be far more complex [32].

\section{Sleep and Circadian Rhythm Regulation}

The role for the $5-\mathrm{HT}_{7} \mathrm{Rs}$ in mood disorders is closely linked to the regulation of sleep and circadian rhythms [38]. Similar to the actions of antidepressant drugs, the blockade of $5-\mathrm{HT}_{7} \mathrm{Rs}$ was shown to alter rapid eye movement (REM) sleep parameters in the opposite direction to the abnormalities found in depression patients. Specifically, $5-\mathrm{HT}_{7} \mathrm{R} \mathrm{KO}$ mice spent less time in and demonstrated less frequent episodes of REM sleep [22]. Similar changes in REM sleep patterns were demonstrated after administration of $5-\mathrm{HT}_{7} \mathrm{R}$ antagonists, including SB-269970, SB656104 and JNJ-18038683 [24, 39]. Moreover, both genetic inactivation and pharmacological blockade augmented the effects of SSRIs on REM sleep suppression [24, 40]. The effect of a $5-\mathrm{HT}_{7} \mathrm{R}$ blockade on REM sleep translates from rodent to humans, as JNJ-18038683 was also found to increase REM latency and decrease REM sleep duration in healthy volunteers [16]. Of note is the recent observation that the $5-\mathrm{HT}_{7} \mathrm{R}$ agonist $\mathrm{LP}-211$ also 
suppressed REM sleep [41]. It has been proposed that activation of $5-\mathrm{HT}_{7} \mathrm{Rs}$ expressed by $\gamma$-aminobutyric acid (GABA)-ergic interneurons decreases the activity of REM sleep-promoting cholinergic neurons in the laterodorsal and pedunculopontine tegmental (LDT/PPT) nuclei and reduces REM sleep (reviewed by Monti and Jantos [38]). On the other hand, suppression of REM sleep by $5-\mathrm{HT}_{7} \mathrm{R}$ antagonists may involve the reduction of GABA-induced inhibition of serotonergic cells that leads to the increase of 5-HT release at postsynaptic sites critical for REM sleep occurrence, including the LDT/PPT nuclei [39].

$5-\mathrm{HT}_{7} \mathrm{Rs}$ have also been implicated in the regulation of the mammalian circadian clock located in the suprachiasmatic nuclei (SCN). In vitro and in vivo studies have demonstrated that 8-OH-DPAT-induced non-photic phase resetting was mediated by the $5-\mathrm{HT}_{7} \mathrm{R}$, as the shift was blocked by genetic inactivation or antagonists of those receptors, including SB-269970, DR-4004 and JNJ18038683 [21, 42-45]. In line with these data, a selective agonist of 5-HT ${ }_{7} \mathrm{Rs}, \mathrm{LP}-211$, induced a phase advancement on spontaneous circadian rhythm in mice [46]. Moreover, another $5-\mathrm{HT}_{7} \mathrm{R}$ agonist, AS19, shortened the period length of PER2 bioluminescence in explants of SCN from PER2::LUC mice genetically modified to report changes in the expression of a key clock protein [47]. This reduction was blocked by SB-269970, a selective 5-HT 7 R antagonist.

The $5-\mathrm{HT}_{7} \mathrm{R}$ is probably also involved in 5-HT-mediated suppression of photic activation of the SCN [48]. However, a 5- $\mathrm{HT}_{7} \mathrm{R}$ agonist, AS-19, failed to inhibit lightinduced phase shifts [49]. The lack of effect may be ascribed to the low efficacy of the tested compound [50].

It has also been suggested that a multimodal approach based on a combination of SSRIs and 5- $\mathrm{HT}_{7} \mathrm{R}$ antagonists may be beneficial in treating patients suffering from poor circadian rhythm synchrony. In rodent models, the combination of escitalopram and SB-269970 produced a greater impact on circadian rhythms than that observed with either agent alone [47]. In this study, combination of inactive doses of escitalopram $(2.5-10 \mathrm{mg} / \mathrm{kg})$ and SB$269970(10-30 \mathrm{mg} / \mathrm{kg})$ produced robust phase delays in rats given access to running wheels. In line with these data, vortioxetine, the SSRI exhibiting antagonistic affinity for $5-\mathrm{HT}_{7} \mathrm{Rs}$, produced an increase in circadian period length in tissue explants from the SCN of PER2::LUC mice and induced a phase delay in wheel-running behaviour in rats, and this effect was blocked by AS19 [51].

\section{Anxiety}

In contrast to the well-established role for $5-\mathrm{HT}_{7} \mathrm{Rs}$ in depression, their involvement in the regulation of anxietylike behaviours is less consistent. No differences in assays sensitive to anxiety states, that is, in the elevated plus maze or light/dark transfer test, were observed between $5-\mathrm{HT}_{7} \mathrm{R}$ KO mice and wild-type (WT) controls [21, 52]. On the other hand, SB-269970 exerted specific anti-anxiety-like effects in the Vogel conflict test and the elevated plus maze test in rats, as well as in the four-plate test in mice [25]. Moreover, SB-269970 reduced marble burying in mice, a behaviour linked to obsessive-compulsive disorder and anxiety [53]. Nevertheless, the compound's efficacy in this test probably reflects antidepressant-like activity. It has also been reported recently that LP-211, an agonist of $5-\mathrm{HT}_{7} \mathrm{Rs}$, reduces anxiety-like behaviour in the black and white box test and the dark/light test in mice [46]. Moreover, rats chronically treated during adolescence with LP211 showed reduced anxiety-related behaviour in adulthood [54].

\section{Cognition}

It has been demonstrated that the $5-\mathrm{HT}_{7} \mathrm{R}$ is involved in hippocampal-dependent cognitive processes (reviewed by Roberts and Hedlund [55]). Accordingly, 5- $\mathrm{HT}_{7} \mathrm{R} \mathrm{KO}$ mice demonstrated impairments of contextual hippocampal-dependent learning and displayed decreased long-term synaptic plasticity within the CA1 region of the hippocampus [52]. Moreover, hippocampus-associated spatial memory deficits in the novel location test were demonstrated in mice with either genetic or pharmacological inactivation of 5-HT $\mathrm{H}_{7} \mathrm{Rs}$ [56]. Data from the Barnes maze test suggested the impaired ability of $5-\mathrm{HT}_{7} \mathrm{KO}$ mice to utilise hippocampal-dependent allocentric memory [56]. Interestingly, it has been hypothesised that the decrease in the hippocampal expression of $5-\mathrm{HT}_{7} \mathrm{R}$ may underlie age-related deficits in allocentric spatial navigation [57].

The role of $5-\mathrm{HT}_{7} \mathrm{R}$ was also evaluated in the novel object recognition test (NORT). $5-\mathrm{HT}_{7} \mathrm{R}$ KO mice did not differ in their ability to discriminate a novel object from the WT mice [56], whereas SB-269970 exerted no effect or even improved recognition memory when administered before the acquisition trial $[56,58]$. On the other hand, SB269970 was shown to induce a NORT deficit when administered during the consolidation phase in mice [59]. At the same time, the improvement was noted after $5-\mathrm{HT}_{7} \mathrm{R}$ activation. Thus, it seems likely that $5-\mathrm{HT}_{7} \mathrm{R}$ may play a different role in the acquisition and consolidation of recognition memory. Moreover, changes in the expression of $5-\mathrm{HT}_{7} \mathrm{R}$ may underlie novelty-seeking behaviour in rats that in turn also affects their ability to discriminate objects $[60,61]$.

In an autoshaping Pavlovian/instrumental learning task, AS19 impaired short-term memory (STM) but improved long-term memory (LTM) [62, 63]. Another 5-HT 7 agonist, 
LP-211, did not affect STM, but it improved LTM [64], (reviewed in detail by Meneses [65]). The pro-cognitive actions of either AS19 or LP-211 were blocked by the 5-HT $\mathrm{H}_{7} \mathrm{R}$ antagonist SB-269970. The 5-HT ${ }_{7} \mathrm{R}$ agonists LP44 and AS19 failed to facilitate emotional memory in the passive avoidance task in mice [50]. However, the lack of effect was ascribed to the low efficacy of LP-44 and AS19 for stimulating protein phosphorylation of $5-\mathrm{HT}_{7} \mathrm{R}$-activated signalling cascades. Data from our laboratory indicate that AS19 also did not affect rats' performance on the attentional set-shifting task (ASST) [66]. Conversely, SB$269970(1 \mathrm{mg} / \mathrm{kg})$ enhanced cognitive flexibility on the ASST. Moreover, SB-269970 (1 mg/kg) was demonstrated to improve reference, but not working, memory as assessed in a radial arm maze task [67]. It might be concluded that increasing the task complexity allows for revealing the procognitive effects of $5-\mathrm{HT}_{7} \mathrm{R}$ blockade.

Although the role of $5-\mathrm{HT}_{7} \mathrm{Rs}$ in modulating cognitive processes under physiological conditions is not fully understood [55, 65, 68, 69], recent reports suggest the efficacy of $5-\mathrm{HT}_{7} \mathrm{R}$ ligands in overcoming cognitive impairments in disease models (described below).

\section{Schizophrenia}

A possible role for $5-\mathrm{HT}_{7} \mathrm{R} \mathrm{s}$ in the pathophysiology of schizophrenia was suggested by post mortem studies that demonstrated marked reductions in the level of $5-\mathrm{HT}_{7} \mathrm{Rs}$ in the prefrontal cortex of schizophrenia patients [70, 71]. Moreover, a genetic polymorphism study found a positive association between the $5-\mathrm{HT}_{7} \mathrm{R}$ gene and schizophrenia [72].

Thus, $5-\mathrm{HT}_{7} \mathrm{R}$ antagonists have been evaluated in animal models predictive of antipsychotic-like activity, based on the administration of amphetamine or antagonists of $\mathrm{N}$ methyl-D aspartic acid (NMDA) receptors. Antagonists of the NMDA receptors, such as phencyclidine (PCP), ketamine or dizocilpine, may evoke not only behaviours reflecting positive symptoms (e.g. hyperactivity) but also negative symptoms (e.g. social withdrawal) and cognitive impairments [73].

The $5-\mathrm{HT}_{7} \mathrm{R}$ antagonist SB-269970 significantly blocked amphetamine-, PCP- and ketamine-induced hyperactivity in rats and mice $[58,74]$. Another $5-\mathrm{HT}_{7} \mathrm{R}$ antagonist, SB-258741, also reversed amphetamine-induced hyperactivity but reduced motility of rats at similar doses [75]. Schizophrenic patients also suffer from disturbances in information processing, reflected as a deficient sensorimotor gating, which may contribute to the cognitive deficits that characterise this disorder [76]. Thus, several studies assessed the effects of a $5-\mathrm{HT}_{7} \mathrm{R}$ antagonist on an operational measure of sensorimotor gating, i.e. prepulse inhibition (PPI) of the startle reflex. Accordingly, SB269970 did not reverse the deficits in PPI evoked by ketamine in rats [77] and mice [74] or by PCP in rats and mice [78]. On the other hand, SB-269970 blocked the amphetamine-induced PPI deficits in mice [74]. However, $5-\mathrm{HT}_{7} \mathrm{Rs}$ may play a partial role in the glutamatergic PPI model, as $5-\mathrm{HT}_{7} \mathrm{R}$ KO mice were less prone to the PCPinduced disruption of PPI than WT mice [78]. In addition, another $5-\mathrm{HT}_{7} \mathrm{R}$ antagonist, SB-258741, normalised PCPdisrupted PPI but was ineffective in the amphetaminebased model [75].

Pro-cognitive effects of $5-\mathrm{HT}_{7} \mathrm{R}$ antagonists in animal models of schizophrenia have been supported by several studies. Specifically, deficits of prefrontal cortex functions, a core feature of schizophrenia, have been ameliorated by the blockade of 5-HT 7 Rs. Accordingly, SB-269970 attenuated the PCP-induced deficits in reversal learning [79], the dizocilpine-induced impairment in working memory as assessed in a delayed non-matching to position task in rats [80] and ketamine-induced cognitive inflexibility on the ASST in rats in our hands [77]. SB-269970 also reversed memory deficits demonstrated in an autoshaping Pavlovian instrumental learning task in rats after systemic administration of dizocilpine [81] or after an intra-prefrontal infusion of ketamine [82]. The compound was also effective against ketamine- and PCP-induced deficits in the NORT in rats $[77,83]$. Moreover, another antagonist of $5-\mathrm{HT}_{7} \mathrm{Rs}$, SB-656104-A, reversed dizocilpine-induced learning and memory impairments in the passive avoidance and Morris water maze tests in rats [84].

The pharmacological blockade of $5-\mathrm{HT}_{7} \mathrm{Rs}$ may also have therapeutic implications for the treatment of negative symptoms in schizophrenia. Although SB-25874 had no beneficial effects on PCP-evoked deficits in social interactions [75], SB-269970 ameliorated ketamine-induced social withdrawal in rats [77].

Experimental data suggest the role of $5-\mathrm{HT}_{7} \mathrm{R}$ antagonism in the pro-cognitive actions of the antipsychotic drugs amisulpride and lurasidone. Co-treatment with the 5- $\mathrm{HT}_{7} \mathrm{R}$ agonist AS19 reversed the abilities of amisulpride and lurasidone to ameliorate the PCP-induced deficits in the NORT in rats [83] as well as blocked the attenuating effects of lurasidone on the MK-801-induced deficits in the rat passive avoidance test [85]. The amisulpride-induced enhancement of set-shifting ability was also blocked by AS19 [66]. Additionally, the antagonism of $5-\mathrm{HT}_{7} \mathrm{Rs}$ may contribute to the mechanisms underlying the pro-social action of amisulpride in rats [86]. It cannot be excluded that the $5-\mathrm{HT}_{7} \mathrm{R}$ may be involved in pro-cognitive effects of other antipsychotic drugs (as for example clozapine) that also possess high affinities for the $5-\mathrm{HT}_{7} \mathrm{R}$ [87]. 


\section{Pain}

Several preclinical findings support the utility of $5-\mathrm{HT}_{7} \mathrm{R}$ agonists in treating neuropathic pain. Accordingly, AS19 and E-55888 reversed mechanical hypersensitivity induced by capsaicin in mice, a model predictive of the anti-nociceptive action of analgesics in neuropathic pain [18]. Moreover, activation of $5-\mathrm{HT}_{7} \mathrm{Rs}$ also reduced the nerve injury-evoked mechanical and thermal hyperalgesia in a model of sciatic nerve ligation in mice [88] and rats [89]. This approach may also be effective in treating diabetic neuropathic pain, as AS19 reduced thermal hyperalgesia in streptozotocin-induced experimental diabetes in mice [90].

However, the role for $5-\mathrm{HT}_{7} \mathrm{R}$ in modulation of pain seems to be quite complex (reviewed by Viguier et al. [91]). Indeed, it has been demonstrated that under sensitising neuropathic conditions, activation of $5-\mathrm{HT}_{7} \mathrm{Rs}$ exerts anti-nociceptive effects at the level of the spinal cord but pro-nociceptive effects in the periphery [92]. However, after systemic administration of $5-\mathrm{HT}_{7} \mathrm{R}$ agonists, the antinociceptive effect mediated by central $5-\mathrm{HT}_{7} \mathrm{Rs}$ seems to predominate. Moreover, the effects of $5-\mathrm{HT}_{7} \mathrm{R}$ agonists may be different in neuropathic versus intact healthy animals. For example, AS19 exerted a pro-nociceptive action in healthy rats but alleviated nerve injury-evoked hyperalgesia [91].

\section{Epilepsy}

The 5-HT $\mathrm{H}_{7} \mathrm{R}$ has also been linked to seizure activity. The $5-\mathrm{HT}_{7} \mathrm{R}$ antagonist SB-258719 was effective in reducing spontaneous epileptic activity in the WAG/Rij rat model of absence epilepsy [93]. In pilocarpine-induced rat models of temporal lobe epilepsy, the 5-HT 7 R antagonist SB-269970 also reduced the number of seizures [94]. The opposite effect was demonstrated by the $5-\mathrm{HT}_{7} \mathrm{R}$ agonist AS19 in that model. In contrast to pharmacological data, a deletion of the $5-\mathrm{HT}_{7} \mathrm{R}$ decreased the electrical and chemical seizure thresholds [95]. In line with these data, the efficacy of 5-CT against convulsions produced by picrotoxin was blocked by SB-269970 [96]. Thus, data appear inconsistent as to whether an activation or blockade of $5-\mathrm{HT}_{7} \mathrm{Rs}$ will produce antiepileptic activity.

\section{Other Implications}

The ligands of $5-\mathrm{HT}_{7} \mathrm{Rs}$ may also be considered as a possible novel therapeutic target in autism spectrum disorders (discussed in detail by Ciranna and Catania [97]). Key evidence comes from a study demonstrating that $5-\mathrm{HT}_{7} \mathrm{R}$ activation by LP-211 corrected excessive metabotropic glutamate receptor-mediated LTD in Fmr1KO mice, a model of Fragile X Syndrome also considered as an animal model of autism [98].

Recently, LP-211 was demonstrated to improve Rett Syndrome-related defective performance, including the anxiety-related profile, motor abilities and memory, in a mouse genetic model of the disease [99].

It has also been demonstrated that the activation of $5-\mathrm{HT}_{7} \mathrm{Rs}$ is responsible for serotonin-evoked cranial vasodilatation, which is considered to be one of the mechanisms involved in migraines. Accordingly, the 5-HT 7 R antagonist SB-269970 inhibited the 5-CT-induced dilatation in the middle meningeal artery in rats [100]. SB269970 also reduced neurogenic dural vasodilation evoked by electrical stimulation of dura mater, whereas the 5- $\mathrm{HT}_{7} \mathrm{R}$ agonist AS19 increased it [101].

Preclinical studies have demonstrated the involvement of $5-\mathrm{HT}_{7} \mathrm{R}$ in the modulation of impulsivity [102], arousal [46] and novelty-seeking behaviour [60, 61, 103]. Thus, possible links to attention-deficit hyperactivity disorder may also be suggested.

Finally, the involvement of $5-\mathrm{HT}_{7} \mathrm{Rs}$ in processes that contribute to the development and maintenance of addictive behaviours may suggest a potential role for these receptors in alcohol and drug dependence (reviewed in detail by Hauser et al. [104]).

\section{Summary}

Evidence supports the role for the $5-\mathrm{HT}_{7} \mathrm{R}$ in a wide range of pathological processes. Nevertheless, only one published study has been designed to assess the clinical efficacy of a 5-HT 7 R antagonist, JNJ-18038683, in patients with depression [16]. Unfortunately, this clinical trial was reported as a failed study lacking assay sensitivity due to a high placebo response. Some examples of the utility of $5-\mathrm{HT}_{7} \mathrm{R}$ blockade may be clinically effective drugs such as amisulpride, lurasidone or vortioxetine that are characterised by having significant affinity for $5-\mathrm{HT}_{7} \mathrm{R}[23,29$, 30].

One may notice the heterogeneous results regarding the effects of both antagonists and agonists of 5-HT 7 Rs, which may hamper the clinical validation of the ligands of this receptor. For example 5- $\mathrm{HT}_{7} \mathrm{R}$ antagonists exhibit an antidepressant-like activity, but REM sleep suppression may be induced by either agonists or antagonists of those receptors [38]. Moreover, both agonists and antagonists may exert anxiolytic-like effects [25, 46]. Similarly, $5-\mathrm{HT}_{7} \mathrm{R}$ is necessary for hippocampal-dependent functions [55], and the activation of this receptor reversed memory deficits on a hippocampal-dependent task in a mouse model of Rett syndrome [99]. On the other hand, antagonists of 
5-HT ${ }_{7}$ Rs may be beneficial in treating schizophrenia-like cognitive impairments [77, 83]. This may stem from technical reasons like the use of unselective 5-HT agonists or a low efficacy of available compounds, as, for example, AS19 [50]. Moreover, dual agonist/antagonist properties were reported for LP-211 [105]. It has also been suggested that $5-\mathrm{HT}_{7} \mathrm{R}$-mediated signalling does not fit a two-state activation/blockade model [38]. The role of the $5-\mathrm{HT}_{7} \mathrm{R}$ may depend on the brain region [38] and neurochemical environment (e.g. serotonin level) [69] and may differ between physiological and pathological conditions [91]. Moreover, alternative signalling pathways and homo/ heterodimerisations reveal a complex picture of the $5-\mathrm{HT}_{7} \mathrm{R}[106,107]$. Of note is also the concept of so called biased agonism or functional selectivity at GPCRs, which implies that different ligands can activate distinct signalling pathways and differentially regulate desensitization, internalization, down-regulation and dimerization processes [108]. It is possible that biased agonism may explain differential effects between different $5-\mathrm{HT}_{7} \mathrm{R}$ antagonists/agonists and even similar effects shared between agonists and antagonists [10, 109]. Thus, further studies are necessary to extend our knowledge of the $5-\mathrm{HT}_{7} \mathrm{Rs}$ and therapeutic potential of their ligands.

Acknowledgments This study was supported by the Statutory Funds of the Institute of Pharmacology, the Polish Academy of Sciences, Kraków, Poland.

Conflict of interest None declared.

Open Access This article is distributed under the terms of the Creative Commons Attribution Noncommercial License which permits any noncommercial use, distribution, and reproduction in any medium, provided the original author(s) and the source are credited.

\section{References}

1. Bard JA, Zgombick J, Adham N, Vaysse P, Branchek TA, Weinshank RL. Cloning of a novel human serotonin receptor (5HT7) positively linked to adenylate cyclase. J Biol Chem. 1993;268(31):23422-6.

2. Lovenberg TW, Baron BM, de Lecea L, Miller JD, Prosser RA, Rea MA, Foye PE, Racke M, Slone AL, Siegel BW. A novel adenylyl cyclase-activating serotonin receptor (5-HT7) implicated in the regulation of mammalian circadian rhythms. Neuron. 1993;11(3):449-58.

3. Ruat M, Traiffort E, Leurs R, Tardivel-Lacombe J, Diaz J, Arrang JM, Schwartz JC. Molecular cloning, characterization, and localization of a high-affinity serotonin receptor (5-HT7) activating cAMP formation. Proc Natl Acad Sci. 1993;90(18): $8547-51$

4. Heidmann DE, Szot P, Kohen R, Hamblin MW. Function and distribution of three rat 5-hydroxytryptamine7 (5-HT7) receptor isoforms produced by alternative splicing. Neuropharmacology. 1998;37(12):1621-32.
5. Krobert KA, Bach T, Syversveen T, Kvingedal AM, Levy FO. The cloned human 5-HT7 receptor splice variants: a comparative characterization of their pharmacology, function and distribution. Naunyn Schmiedebergs Arch Pharmacol. 2001;363 (6):620-32.

6. Guthrie CR, Murray AT, Franklin AA, Hamblin MW. Differential agonist-mediated internalization of the human 5-hydroxytryptamine 7 receptor isoforms. J Pharmacol Exp Ther. 2005;313(3):1003-10.

7. Kvachnina E, Liu G, Dityatev A, Renner U, Dumuis A, Richter DW, Dityateva G, Schachner M, Voyno-Yasenetskaya TA, Ponimaskin EG. 5-HT7 receptor is coupled to G alpha subunits of heterotrimeric G12-protein to regulate gene transcription and neuronal morphology. J Neurosci. 2005;25(34):7821-30.

8. Kvachnina E, Dumuis A, Wlodarczyk J, Renner U, Cochet M, Richter DW, Ponimaskin E. Constitutive Gs-mediated, but not G12-mediated, activity of the 5-hydroxytryptamine 5-HT7(a) receptor is modulated by the palmitoylation of its C-terminal domain. Biochim Biophys Acta. 2009;1793(11): 1646-55.

9. Kobe F, Guseva D, Jensen TP, Wirth A, Renner U, Hess D, Muller M, Medrihan L, Zhang W, Zhang M, Braun K, Westerholz S, Herzog A, Radyushkin K, El-Kordi A, Ehrenreich H, Richter DW, Rusakov DA, Ponimaskin E. 5-HT7R/G12 signaling regulates neuronal morphology and function in an agedependent manner. J Neurosci. 2012;32(9):2915-30.

10. Teitler M, Toohey N, Knight JA, Klein MT, Smith C. Clozapine and other competitive antagonists reactivate risperidone-inactivated h5-HT7 receptors: radioligand binding and functional evidence for GPCR homodimer protomer interactions. Psychopharmacology (Berl). 2010;212(4):687-97.

11. Renner U, Zeug A, Woehler A, Niebert M, Dityatev A, Dityateva G, Gorinski N, Guseva D, Abdel-Galil D, Frohlich M, Doring F, Wischmeyer E, Richter DW, Neher E, Ponimaskin EG. Heterodimerization of serotonin receptors 5-HT1A and 5-HT7 differentially regulates receptor signalling and trafficking. J Cell Sci. 2012;125(Pt 10):2486-99.

12. Kikuchi C, Nagaso H, Hiranuma T, Koyama M. Tetrahydrobenzindoles: selective antagonists of the 5-HT7 receptor. J Med Chem. 1999;42(4):533-5.

13. Thomas DR, Gittins SA, Collin LL, Middlemiss DN, Riley G, Hagan J, Gloger I, Ellis CE, Forbes IT, Brown AM. Functional characterisation of the human cloned 5-HT7 receptor (long form); antagonist profile of SB-258719. $\mathrm{Br} \mathrm{J}$ Pharmacol. 1998;124(6):1300-6.

14. Hagan JJ, Price GW, Jeffrey P, Deeks NJ, Stean T, Piper D, Smith MI, Upton N, Medhurst AD, Middlemiss DN, Riley GJ, Lovell PJ, Bromidge SM, Thomas DR. Characterization of SB269970-A, a selective 5-HT(7) receptor antagonist. Br J Pharmacol. 2000;130(3):539-48.

15. Thomas DR, Melotto S, Massagrande M, Gribble AD, Jeffrey $P$, Stevens AJ, Deeks NJ, Eddershaw PJ, Fenwick SH, Riley G, Stean T, Scott CM, Hill MJ, Middlemiss DN, Hagan JJ, Price GW, Forbes IT. SB-656104-A, a novel selective 5-HT7 receptor antagonist, modulates REM sleep in rats. $\mathrm{Br} \mathrm{J}$ Pharmacol. 2003;139(4):705-14.

16. Bonaventure P, Dugovic C, Kramer M, De Boer P, Singh J, Wilson S, Bertelsen K, Di J, Shelton J, Aluisio L, Dvorak L, Fraser I, Lord B, Nepomuceno D, Ahnaou A, Drinkenburg W, Chai W, Dvorak C, Sands S, Carruthers N, Lovenberg TW. Translational evaluation of JNJ-18038683, a 5-hydroxytryptamine type 7 receptor antagonist, on rapid eye movement sleep and in major depressive disorder. J Pharmacol Exp Ther. 2012;342(2):429-40.

17. Di Pilato P, Niso M, Adriani W, Romano E, Travaglini D, Berardi F, Colabufo NA, Perrone R, Laviola G, Lacivita E, 
Leopoldo M. Selective agonists for serotonin 7 (5-HT7) receptor and their applications in preclinical models: an overview. Rev Neurosci. 2014;25(3):401-15.

18. Brenchat A, Romero L, Garcia M, Pujol M, Burgueno J, Torrens A, Hamon M, Baeyens JM, Buschmann H, Zamanillo D, Vela JM. 5-HT7 receptor activation inhibits mechanical hypersensitivity secondary to capsaicin sensitization in mice. Pain. 2009;141(3):239-47.

19. Leopoldo M, Lacivita E, Contino M, Colabufo NA, Berardi F, Perrone R. Structure-activity relationship study on $N-(1,2,3,4-$ tetrahydronaphthalen-1-yl)-4-aryl-1-piperazinehexanamides, a class of 5-HT7 receptor agents. 2. J Med Chem. 2007;50(17): 4214-21.

20. Leopoldo M, Lacivita E, De Giorgio P, Fracasso C, Guzzetti S, Caccia S, Contino M, Colabufo NA, Berardi F, Perrone R. Structural modifications of $N$-(1,2,3,4-tetrahydronaphthalen-1yl)-4-aryl-1-piperazinehexanamides: influence on lipophilicity and 5-HT7 receptor activity. Part III. J Med Chem. 2008;51(18): 5813-22.

21. Guscott M, Bristow LJ, Hadingham K, Rosahl TW, Beer MS, Stanton JA, Bromidge F, Owens AP, Huscroft I, Myers J, Rupniak NM, Patel S, Whiting PJ, Hutson PH, Fone KC, Biello SM, Kulagowski JJ, McAllister G. Genetic knockout and pharmacological blockade studies of the 5-HT7 receptor suggest therapeutic potential in depression. Neuropharmacology. 2005; 48(4):492-502.

22. Hedlund PB, Huitron-Resendiz S, Henriksen SJ, Sutcliffe JG. 5-HT7 receptor inhibition and inactivation induce antidepressant like behavior and sleep pattern. Biol Psychiatry. 2005;58(10): 831-7.

23. Sarkisyan G, Roberts AJ, Hedlund PB. The 5-HT(7) receptor as a mediator and modulator of antidepressant-like behavior. Behav Brain Res. 2010;209(1):99-108.

24. Bonaventure P, Kelly L, Aluisio L, Shelton J, Lord B, Galici R, Miller K, Atack J, Lovenberg TW, Dugovic C. Selective blockade of 5-hydroxytryptamine (5-HT)7 receptors enhances 5-HT transmission, antidepressant-like behavior, and rapid eye movement sleep suppression induced by citalopram in rodents. J Pharmacol Exp Ther. 2007;321(2):690-8.

25. Wesolowska A, Nikiforuk A, Stachowicz K, Tatarczynska E. Effect of the selective 5-HT7 receptor antagonist SB 269970 in animal models of anxiety and depression. Neuropharmacology. 2006;51(3):578-86.

26. Wesolowska A, Kowalska M. Influence of serotonin 5-HT(7) receptor blockade on the behavioral and neurochemical effects of imipramine in rats. Pharmacol Rep. 2008;60(4):464-74.

27. Mnie-Filali O, Faure C, Lambas-Senas L, El MM, Belblidia H, Gondard E, Etievant A, Scarna H, Didier A, Berod A, Blier P, Haddjeri N. Pharmacological blockade of 5-HT7 receptors as a putative fast acting antidepressant strategy. Neuropsychopharmacology. 2011;36(6):1275-88.

28. Wesolowska A, Tatarczynska E, Nikiforuk A, ChojnackaWojcik E. Enhancement of the anti-immobility action of antidepressants by a selective 5-HT7 receptor antagonist in the forced swimming test in mice. Eur J Pharmacol. 2007;555 (1):43-7.

29. Abbas AI, Hedlund PB, Huang XP, Tran TB, Meltzer HY, Roth BL. Amisulpride is a potent 5-HT7 antagonist: relevance for antidepressant actions in vivo. Psychopharmacology (Berl). 2009;205(1):119-28.

30. Cates LN, Roberts AJ, Huitron-Resendiz S, Hedlund PB. Effects of lurasidone in behavioral models of depression. Role of the 5-HT(7) receptor subtype. Neuropharmacology. 2013;70:211-7.

31. Willner P. Validity, reliability and utility of the chronic mild stress model of depression: a 10-year review and evaluation. Psychopharmacology (Berl). 1997;134(4):319-29.
32. Terron JA. Novel insights into the potential involvement of 5-HT7 receptors in endocrine dysregulation in stress-related disorders. Rev Neurosci. 2014;25(3):439-49.

33. Garcia-Iglesias BB, Mendoza-Garrido ME, Gutierrez-Ospina G, Rangel-Barajas C, Noyola-Diaz M, Terron JA. Sensitization of restraint-induced corticosterone secretion after chronic restraint in rats: involvement of 5-HT(7) receptors. Neuropharmacology. 2013;71:216-27.

34. Tokarski K, Pitra P, Duszynska B, Hess G. Imipramine counteracts corticosterone-induced alterations in the effects of the activation of 5-HT(7) receptors in rat hippocampus. J Physiol Pharmacol. 2009;60(2):83-8.

35. Tokarski K, Bobula B, Kusek M, Hess G. The 5-HT(7) receptor antagonist SB 269970 counteracts restraint stress-induced attenuation of long-term potentiation in rat frontal cortex. J Physiol Pharmacol. 2011;62(6):663-7.

36. Li YC, Wang FM, Pan Y, Qiang LQ, Cheng G, Zhang WY, Kong LD. Antidepressant-like effects of curcumin on serotonergic receptor-coupled AC-cAMP pathway in chronic unpredictable mild stress of rats. Prog Neuropsychopharmacol Biol Psychiatry. 2009;33(3):435-49.

37. Nikiforuk A. Selective blockade of 5-HT7 receptors facilitates attentional set-shifting in stressed and control rats. Behav Brain Res. 2012;226(1):118-23.

38. Monti JM, Jantos H. The role of serotonin 5-HT7 receptor in regulating sleep and wakefulness. Rev Neurosci. 2014;25(3): 429-37.

39. Monti JM, Leopoldo M, Jantos H, Lagos P. Microinjection of the 5-HT7 receptor antagonist SB-269970 into the rat brainstem and basal forebrain: site-dependent effects on REM sleep. Pharmacol Biochem Behav. 2012;102(2):373-80.

40. Shelton J, Bonaventure P, Li X, Yun S, Lovenberg T, Dugovic C. 5-HT7 receptor deletion enhances REM sleep suppression induced by selective serotonin reuptake inhibitors, but not by direct stimulation of 5-HT1A receptor. Neuropharmacology. 2009;56(2):448-54.

41. Monti JM, Leopoldo M, Jantos H. Systemic administration and local microinjection into the central nervous system of the 5-HT(7) receptor agonist LP-211 modify the sleep-wake cycle in the rat. Behav Brain Res. 2014;259:321-9.

42. Ehlen JC, Grossman GH, Glass JD. In vivo resetting of the hamster circadian clock by 5 -HT7 receptors in the suprachiasmatic nucleus. J Neurosci. 2001;21(14):5351-7.

43. Gardani M, Biello SM. The effects of photic and nonphotic stimuli in the 5-HT7 receptor knockout mouse. Neuroscience. 2008;152(1):245-53.

44. Sprouse J, Reynolds L, Li X, Braselton J, Schmidt A. 8-OHDPAT as a 5-HT7 agonist: phase shifts of the circadian biological clock through increases in cAMP production. Neuropharmacology. 2004;46(1):52-62.

45. Shelton J, Yun S, Losee OS, Turek F, Bonaventure P, Dvorak C, Lovenberg T, Dugovic C. Selective pharmacological blockade of the 5-HT7 receptor attenuates light and 8-OH-DPAT induced phase shifts of mouse circadian wheel running activity. Front Behav Neurosci. 2014;8:453.

46. Adriani W, Travaglini D, Lacivita E, Saso L, Leopoldo M, Laviola G. Modulatory effects of two novel agonists for serotonin receptor 7 on emotion, motivation and circadian rhythm profiles in mice. Neuropharmacology. 2012;62(2):833-42.

47. Westrich L, Sprouse J, Sanchez C. The effects of combining serotonin reuptake inhibition and 5-HT7 receptor blockade on circadian rhythm regulation in rodents. Physiol Behav. 2013;110-111:42-50.

48. Ying SW, Rusak B. 5-HT7 receptors mediate serotonergic effects on light-sensitive suprachiasmatic nucleus neurons. Brain Res. 1997;755(2):246-54. 
49. Cuesta M, Clesse D, Pevet P, Challet E. New light on the serotonergic paradox in the rat circadian system. J Neurochem. 2009;110(1):231-43.

50. Eriksson TM, Holst S, Stan TL, Hager T, Sjogren B, Ogren SO, Svenningsson P, Stiedl O. 5-HT1A and 5-HT7 receptor crosstalk in the regulation of emotional memory: implications for effects of selective serotonin reuptake inhibitors. Neuropharmacology. 2012;63(6):1150-60.

51. Westrich L, Haddjeri N, Dkhissi-Benyahya O, Sanchez C. Involvement of 5-HT receptors in vortioxetine's modulation of circadian rhythms and episodic memory in rodents. Neuropharmacology. 2014;89C:382-90.

52. Roberts AJ, Krucker T, Levy CL, Slanina KA, Sutcliffe JG, Hedlund PB. Mice lacking 5-HT receptors show specific impairments in contextual learning. Eur J Neurosci. 2004;19(7): 1913-22.

53. Hedlund PB, Sutcliffe JG. The 5-HT7 receptor influences stereotypic behavior in a model of obsessive-compulsive disorder. Neurosci Lett. 2007;414(3):247-51.

54. Canese R, Zoratto F, Altabella L, Porcari P, Mercurio L, de Pasquale F, Butti E, Martino G, Lacivita E, Leopoldo M, Laviola G, Adriani W. Persistent modification of forebrain networks and metabolism in rats following adolescent exposure to a 5-HT7 receptor agonist. Psychopharmacology (Berl). 2015;232(1):75-89.

55. Roberts AJ, Hedlund PB. The 5-HT(7) receptor in learning and memory. Hippocampus. 2012;22(4):762-71.

56. Sarkisyan G, Hedlund PB. The 5-HT7 receptor is involved in allocentric spatial memory information processing. Behav Brain Res. 2009;202(1):26-31.

57. Beaudet G, Bouet V, Jozet-Alves C, Schumann-Bard P, Dauphin F, Paizanis E, Boulouard M, Freret T. Spatial memory deficit across aging: current insights of the role of 5-HT7 receptors. Front Behav Neurosci. 2014;8:448.

58. Waters KA, Stean TO, Hammond B, Virley DJ, Upton N, Kew JN, Hussain I. Effects of the selective 5-HT(7) receptor antagonist SB-269970 in animal models of psychosis and cognition. Behav Brain Res. 2012;228(1):211-8.

59. Freret T, Paizanis E, Beaudet G, Gusmao-Montaigne A, Nee G, Dauphin F, Bouet V, Boulouard M. Modulation of 5-HT7 receptor: effect on object recognition performances in mice. Psychopharmacology (Berl). 2014;231(2):393-400.

60. Ballaz SJ, Akil H, Watson SJ. The 5-HT7 receptor: role in novel object discrimination and relation to novelty-seeking behavior. Neuroscience. 2007;149(1):192-202.

61. Ballaz SJ, Akil H, Watson SJ. Analysis of 5-HT6 and 5-HT7 receptor gene expression in rats showing differences in noveltyseeking behavior. Neuroscience. 2007;147(2):428-38.

62. Meneses A, Perez-Garcia G, Liy-Salmeron G, Flores-Galvez D, Castillo C, Castillo E. The effects of the 5-HT(6) receptor agonist EMD and the 5-HT(7) receptor agonist AS19 on memory formation. Behav Brain Res. 2008;195(1):112-9.

63. Perez-Garcia GS, Meneses A. Effects of the potential 5-HT7 receptor agonist AS 19 in an autoshaping learning task. Behav Brain Res. 2005;163(1):136-40.

64. Meneses A, Perez-Garcia G, Liy-Salmeron G, Ponce-Lopez T, Lacivita E, Leopoldo M. 5-HT receptor activation: procognitive and antiamnesic effects. Psychopharmacology (Berl). 2015;232 (3):595-603

65. Meneses A. 5-HT7 receptor stimulation and blockade: a therapeutic paradox about memory formation and amnesia. Front Behav Neurosci. 2014;8:207.

66. Nikiforuk A, Popik P. Amisulpride promotes cognitive flexibility in rats: the role of 5-HT7 receptors. Behav Brain Res. 2013;248:136-40.
67. Gasbarri A, Cifariello A, Pompili A, Meneses A. Effect of 5-HT(7) antagonist SB-269970 in the modulation of working and reference memory in the rat. Behav Brain Res. 2008;195(1): 164-70.

68. Gasbarri A, Pompili A. Serotonergic 5-HT7 receptors and cognition. Rev Neurosci. 2014;25(3):311-23.

69. Matthys A, Haegeman G, Van CK, Vanhoenacker P. Role of the 5-HT7 receptor in the central nervous system: from current status to future perspectives. Mol Neurobiol. 2011;43(3): 228-53.

70. Dean B, Pavey G, Thomas D, Scarr E. Cortical serotonin7, 1D and $1 \mathrm{~F}$ receptors: effects of schizophrenia, suicide and antipsychotic drug treatment. Schizophr Res. 2006;88(1-3):265-74.

71. East SZ, Burnet PW, Kerwin RW, Harrison PJ. An RT-PCR study of 5-HT(6) and 5-HT(7) receptor mRNAs in the hippocampal formation and prefrontal cortex in schizophrenia. Schizophr Res. 2002;57(1):15-26.

72. Ikeda M, Iwata N, Kitajima T, Suzuki T, Yamanouchi Y, Kinoshita Y, Ozaki N. Positive association of the serotonin 5-HT7 receptor gene with schizophrenia in a Japanese population. Neuropsychopharmacology. 2006;31(4):866-71.

73. Neill JC, Barnes S, Cook S, Grayson B, Idris NF, McLean SL, Snigdha S, Rajagopal L, Harte MK. Animal models of cognitive dysfunction and negative symptoms of schizophrenia: focus on NMDA receptor antagonism. Pharmacol Ther. 2010;128:41932.

74. Galici R, Boggs JD, Miller KL, Bonaventure P, Atack JR. Effects of SB-269970, a 5-HT7 receptor antagonist, in mouse models predictive of antipsychotic-like activity. Behav Pharmacol. 2008;19(2):153-9.

75. Pouzet B, Didriksen M, Arnt J. Effects of the 5-HT(7) receptor antagonist SB-258741 in animal models for schizophrenia. Pharmacol Biochem Behav. 2002;71(4):655-65.

76. Braff DL. Information processing and attention dysfunctions in schizophrenia. Schizophr Bull. 1993;19(2):233-59.

77. Nikiforuk A, Kos T, Fijal K, Holuj M, Rafa D, Popik P. Effects of the selective 5-HT7 receptor antagonist SB-269970 and amisulpride on ketamine-induced schizophrenia-like deficits in rats. PLoS One. 2013;8(6):e66695.

78. Semenova S, Geyer MA, Sutcliffe JG, Markou A, Hedlund PB. Inactivation of the 5-HT(7) receptor partially blocks phencyclidine-induced disruption of prepulse inhibition. Biol Psychiatry. 2008;63(1):98-105.

79. McLean SL, Woolley ML, Thomas D, Neill JC. Role of 5-HT receptor mechanisms in sub-chronic PCP-induced reversal learning deficits in the rat. Psychopharmacology (Berl). 2009;206(3):403-14.

80. Bonaventure P, Aluisio L, Shoblock J, Boggs JD, Fraser IC, Lord B, Lovenberg TW, Galici R. Pharmacological blockade of serotonin 5-HT(7) receptor reverses working memory deficits in rats by normalizing cortical glutamate neurotransmission. PLoS One. 2011;6(6):e20210.

81. Meneses A. Effects of the 5-HT7 receptor antagonists SB269970 and DR 4004 in autoshaping Pavlovian/instrumental learning task. Behav Brain Res. 2004;155(2):275-82.

82. Liy-Salmeron G, Meneses A. Effects of 5-HT drugs in prefrontal cortex during memory formation and the ketamine amnesiamodel. Hippocampus. 2008;18(9):965-74.

83. Horiguchi M, Huang M, Meltzer HY. The role of 5-hydroxytryptamine 7 receptors in the phencyclidine-induced novel object recognition deficit in rats. J Pharmacol Exp Ther. 2011;338(2):605-14.

84. Horisawa $\mathrm{T}$, Ishibashi $\mathrm{T}$, Nishikawa $\mathrm{H}$, Enomoto $\mathrm{T}$, Toma $\mathrm{S}$, Ishiyama T, Taiji $\mathrm{M}$. The effects of selective antagonists of serotonin 5-HT7 and 5-HT1A receptors on MK-801-induced 
impairment of learning and memory in the passive avoidance and Morris water maze tests in rats: mechanistic implications for the beneficial effects of the novel atypical antipsychotic lurasidone. Behav Brain Res. 2011;220(1):83-90.

85. Horisawa T, Nishikawa H, Toma S, Ikeda A, Horiguchi M, Ono M, Ishiyama T, Taiji M. The role of 5-HT7 receptor antagonism in the amelioration of MK-801-induced learning and memory deficits by the novel atypical antipsychotic drug lurasidone. Behav Brain Res. 2013;244:66-9.

86. Hołuj M, Popik P, Nikiforuk A. Improvement of ketamine-induced social withdrawal in rats: the role of 5-HT7 receptors. Behav Pharmacol. 2015. doi:10.1097/FBP.0000000000000132.

87. Roth BL, Craigo SC, Choudhary MS, Uluer A, Monsma FJ Jr, Shen Y, Meltzer HY, Sibley DR. Binding of typical and atypical antipsychotic agents to 5-hydroxytryptamine-6 and 5-hydroxytryptamine-7 receptors. J Pharmacol Exp Ther. 1994;268(3): 1403-10.

88. Brenchat A, Nadal X, Romero L, Ovalle S, Muro A, SanchezArroyos R, Portillo-Salido E, Pujol M, Montero A, Codony X, Burgueno J, Zamanillo D, Hamon M, Maldonado R, Vela JM. Pharmacological activation of 5-HT7 receptors reduces nerve injury-induced mechanical and thermal hypersensitivity. Pain. 2010;149(3):483-94.

89. Viguier F, Michot B, Kayser V, Bernard JF, Vela JM, Hamon M, Bourgoin S. GABA, but not opioids, mediates the anti-hyperalgesic effects of 5-HT7 receptor activation in rats suffering from neuropathic pain. Neuropharmacology. 2012;63(6):1093-106.

90. Ulugol A, Oltulu C, Gunduz O, Citak C, Carrara R, Shaqaqi MR, Sanchez AM, Dogrul A. 5-HT7 receptor activation attenuates thermal hyperalgesia in streptozocin-induced diabetic mice. Pharmacol Biochem Behav. 2012;102(2):344-8.

91. Viguier F, Michot B, Hamon M, Bourgoin S. Multiple roles of serotonin in pain control mechanisms-implications of 5-HT(7) and other 5-HT receptor types. Eur J Pharmacol. 2013;716 (1-3):8-16.

92. Brenchat A, Zamanillo D, Hamon M, Romero L, Vela JM. Role of peripheral versus spinal 5-HT(7) receptors in the modulation of pain undersensitizing conditions. Eur J Pain. 2012;16(1): $72-81$.

93. Graf M, Jakus R, Kantor S, Levay G, Bagdy G. Selective 5-HT1A and 5-HT7 antagonists decrease epileptic activity in the WAG/Rij rat model of absence epilepsy. Neurosci Lett. 2004;359(1-2):45-8.

94. Yang Z, Liu X, Yin Y, Sun S, Deng X. Involvement of 5-HT(7) receptors in the pathogenesis of temporal lobe epilepsy. Eur $\mathbf{J}$ Pharmacol. 2012;685(1-3):52-8.

95. Witkin JM, Baez M, Yu J, Barton ME, Shannon HE. Constitutive deletion of the serotonin-7 (5-HT(7)) receptor decreases electrical and chemical seizure thresholds. Epilepsy Res. 2007;75(1):39-45.

96. Pericic D, Svob SD. The role of 5-HT(7) receptors in the control of seizures. Brain Res. 2007;1141:48-55.

97. Ciranna L, Catania MV. 5-HT7 receptors as modulators of neuronal excitability, synaptic transmission and plasticity: physiological role and possible implications in autism spectrum disorders. Front Cell Neurosci. 2014;8:250.

98. Costa L, Spatuzza M, D’Antoni S, Bonaccorso CM, Trovato C, Musumeci SA, Leopoldo M, Lacivita E, Catania MV, Ciranna
L. Activation of 5-HT7 serotonin receptors reverses metabotropic glutamate receptor-mediated synaptic plasticity in wild-type and Fmr1 knockout mice, a model of Fragile X syndrome. Biol Psychiatry. 2012;72(11):924-33.

99. De Filippis B, Nativio P, Fabbri A, Ricceri L, Adriani W, Lacivita E, Leopoldo M, Passarelli F, Fuso A, Laviola G. Pharmacological stimulation of the brain serotonin receptor 7 as a novel therapeutic approach for Rett syndrome. Neuropsychopharmacology. 2014;39(11):2506-18.

100. Terron JA, Martinez-Garcia E. 5-HT7 receptor-mediated dilatation in the middle meningeal artery of anesthetized rats. Eur J Pharmacol. 2007;560(1):56-60.

101. Wang X, Fang Y, Liang J, Yan M, Hu R, Pan X. 5-HT7 receptors are involved in neurogenic dural vasodilatation in an experimental model of migraine. J Mol Neurosci. 2014;54(2): 164-70.

102. Leo D, Adriani W, Cavaliere C, Cirillo G, Marco EM, Romano E, di Porzio U, Papa M, Perrone-Capano C, Laviola G. Methylphenidate to adolescent rats drives enduring changes of accumbal Htr7 expression: implications for impulsive behavior and neuronal morphology. Genes Brain Behav. 2009;8(3): 356-68.

103. Ruocco LA, Romano E, Treno C, Lacivita E, Arra C, GironiCarnevale UA, Travaglini D, Leopoldo M, Laviola G, Sadile AG, Adriani W. Emotional and risk seeking behavior after prepuberal subchronic or adult acute stimulation of 5-HT7-Rs in Naples High Excitability rats. Synapse. 2014;68(4):159-67.

104. Hauser SR, Hedlund PB, Roberts AJ, Sari Y, Bell RL, Engleman EA. The 5-HT7 receptor as a potential target for treating drug and alcohol abuse. Front Neurosci. 2014;8:448.

105. Atanes P, Lacivita E, Rodriguez J, Brea J, Burgueno J, Vela JM, Cadavid MI, Loza MI, Leopoldo M, Castro M. The arylpiperazine derivatives $N$-(4-cyanophenylmethyl)-4-(2-diphenyl)-1piperazinehexanamide and $N$-benzyl-4-(2-diphenyl)-1-piperazinehexanamide exert a long-lasting inhibition of human serotonin 5-HT7 receptor binding and cAMP signaling. Pharmacol Res Perspect. 2013;1(2):e00013.

106. Gellynck E, Heyninck K, Andressen KW, Haegeman G, Levy FO, Vanhoenacker P, Van CK. The serotonin 5-HT7 receptors: two decades of research. Exp Brain Res. 2013;230(4):555-68.

107. Guseva D, Wirth A, Ponimaskin E. Cellular mechanisms of the 5-HT7 receptor-mediated signaling. Front Behav Neurosci. 2014;8:306.

108. Kenakin T. Functional selectivity and biased receptor signaling. J Pharmacol Exp Ther. 2011;336(2):296-302.

109. Krobert KA, Andressen KW, Levy FO. Heterologous desensitization is evoked by both agonist and antagonist stimulation of the human 5-HT(7) serotonin receptor. Eur J Pharmacol. 2006;532(1-2):1-10.

110. Lovell PJ, Bromidge SM, Dabbs S, Duckworth DM, Forbes IT, Jennings AJ, King FD, Middlemiss DN, Rahman SK, Saunders DV, Collin LL, Hagan JJ, Riley GJ, Thomas DR. A novel, potent, and selective 5-HT(7) antagonist: (R)-3-(2-(2-(4methylpiperidin-1-yl)ethyl)pyrrolidine-1-sulfonyl) phen ol (SB269970). J Med Chem. 2000;43(3):342-5.

111. Brenchat A, Ejarque M, Zamanillo D, Vela JM, Romero L. Potentiation of morphine analgesia by adjuvant activation of 5-HT7 receptors. J Pharmacol Sci. 2011;116(4):388-91. 